\title{
Analisis Partisipasi Masyarakat Terhadap Kepatuhan Wajib Pajak dalam Membayar Pajak Bumi dan Bangunan Perdesaan dan Perkotaan (PBB-P2) di UPPRD Johar Baru Jakarta Periode Tahun 2017-2019
}

Fathimatuz Zahra ${ }^{1 *}$ Novianita Rulandari ${ }^{2}$

${ }^{1,2}$ Institut Ilmu Sosial dan Managemen STIAMI, Jakarta, Indonesia

Email: ftzzahra@gmail.com ${ }^{1}$, novianitarulandari@gmail.com ${ }^{2}$

\section{ARTICLE INFO}

\section{Keywords}

Public Participation on WP

Compliance Level, in Paying $P B B-P 2$

\begin{abstract}
Local taxes are one of the sources of local revenue, including for the Johar Baru Jakarta Tax and Retribution Service Unit (UPPRD), which relies on one of the sources of income from the land and building tax revenue for the Rural Urban sector (PBB-P2). This study aims to determine the level of participation and compliance level of taxpayers in paying $P B B-P 2$, the obstacles that have been found and the efforts that have been made. The author uses primary and secondary data which are then analyzed using descriptive qualitative methods. This study found that within three years the level of community participation and level of adherence was quite effective. One of the main factors and efforts that have an impact on public participation as taxpayers, namely the level of knowledge of the taxpayers themselves about the importance of paying taxes, as well as the inactivity of the community as wp in providing information on changes to their tax objects and on building ownership so that the data registered with data is not updated. in the field. Suggestions for the future are to create a new UPPRD Johar official site to make it easier for the public as taxpayers to update their tax object data without requiring the public as taxpayers to report to the UPPRD office
\end{abstract}

\section{PENDAHULUAN}

Pajak merupakan salah satu sumber penghasilan terbesar bagi negara. Aspek penunjang dalam keberhasilan serta pencapaian tujuan pembangunan nasional adalah sumber daya manusia, sumber daya alam, serta ketersediaan dana untuk pembangunan, baik itu yang bersumber dari pajak maupun non pajak. Negara dalam menjalankan roda pemerintahannya memerlukan dana yang cukup besar untuk dapat mensukseskan pembangunan nasional. Dalam 9 tahun terakhir tren kinerja penerimaan pajak belum mencapai target sepenuhnya, hal ini dapat dilihat pada gambar di bawah ini :

Untuk mengoptimalkan pendapatannya, negara perlu menghimpun dana semaksimal mungkin dari sektor pajak, dan mengelola dana tersebut dengan baik. Pajak pusat dan pajak daerah merupakan sumber penerimaan negara. Salah satu pajak yang cukup potensial adalah Pajak Bumi dan Bangunan Perkotaan dan Perdesaan atau yang dikenal PBB P2. PBB P2 merupakan salah satu jenis pajak daerah yang dikenakan atas tanah dan bangunan.

Untuk itu penerimaan terkait PBB sudah dapat berjalan optimal, meski demikian sebenarnya penerimaan PBB masih dapat dimaksimalkan dengan meningkatkan target sesuai dengan potensi pendapatannya. Berikut disampaikan data target dan penerimaan PBB P2 pada salah satu Unit Pendapatan Pajak dan Retribusi Daerah (UPPRD) Johar Baru sebagai berikut : 


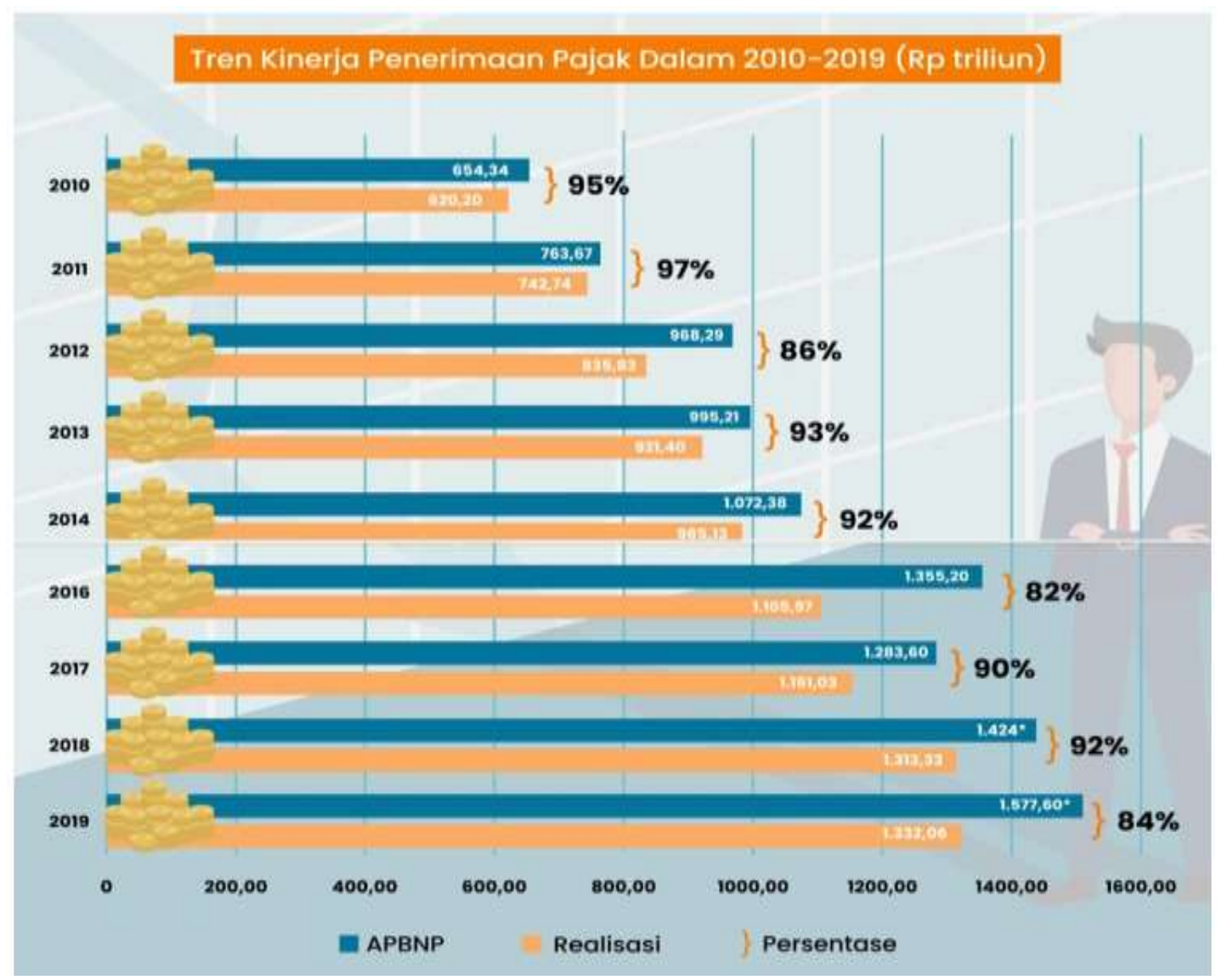

Sumber:https://news.ddtc.co.id/tren-target-dan-realisasi-penerimaan-pajak-satu-dekade-terakhir18772?page_y=1539.199951171875

\begin{tabular}{|c|c|c|c|}
\hline TAHUN & $\begin{array}{c}\text { TARGET } \\
\text { (dalam Rp) }\end{array}$ & $\begin{array}{c}\text { REALLSASI } \\
\text { (dalam Rp) }\end{array}$ & \multicolumn{1}{c|}{ \% } \\
\hline 2017 & 8.187 .0000000 & 8288.036 .024 & $101 \%$ \\
\hline 2018 & 8.748 .000 .000 & 9.232 .283 .632 & $102 \%$ \\
\hline 2019 & 10.0095 .565 .000 & 9.652 .778 .718 & $96 \%$ \\
\hline
\end{tabular}

Sumber: UPPPD Johar Baru Jakata Pusat

Pada tabel diatas dapat dilihat bahwa selama tiga tahun terakhir realisasi penerimaan PBB sudah tercapai dengan sangat baik. Akan tetapi pada saat peneliti melakukan observasi, masih banyak permasalahan dalam pelaksanaan PBB P2, permasalahan utama terkait dengan partisipasi masyarakat. Peneliti mengidentifikasi permasalahan sebagai berikut :

1. Kurangnya partisipasi masyarakat dalam melakukan pembayaran PBB

2. Kurangnya partisipasi masyarakat dalam mengupdate data objek PBB P2

3. Banyaknya wajib PPB P2 yang belum melaksanakan kewajibannya secara tepat waktu

Dari hal diatas UPPRD Johar Baru selaku pemungut PBB-P2 masih menemukan beberapa kendala yaitu terkait kurangnya partisipasi masyarakat dalam memenuhi kewajiban PBB P2. Untuk itu berdasarkan fenomena masalah di atas peneliti melakukan analisis dengan judul Analisis Partisipasi Masyarakat Terhadap 
Kepatuhan Wajib Pajak Dalam Membayar Pajak Bumi Dan Bangunan Perdesaan dan Perkotaan (PBB-P2) di UPPRD Johar Baru Jakarta Periode Tahun 2017-2019.

\section{PERTANYAAN PENELITIAN}

1. Bagaimana partisipasi masyarakat terhadap kepatuhan wajib pajak dalam membayar PBB-P2 di UPPRD Johar Baru Jakarta periode tahun 2017-2019?

2. Apa saja hambatan dalam meningkatkan partisipasi masyarakat terhadap kepatuhan wajib pajak dalam membayar PBB-P2 di UPPRD Johar Baru Jakarta periode tahun 2017-2019?

3. Upaya apa yang dilakukan dalam meningkatkan partisipasi masyarakat terhadap kepatuhan wajib pajak dalam membayar PBB-P2 di UPPRD Johar Baru Jakarta periode tahun 2017-2019?

\section{TUJUAN PENELITIAN}

1. Untuk menganalisis partisipasi masyarakat terhadap kepatuhan wajib pajak dalam membayar PBB-P2 di UPPRD Johar Baru Jakarta periode tahun 2017-2019;

2. Untuk menganalisis apa saja hambatan dalam meningkatkan partisipasi masyarakat terhadap kepatuhan wajib pajak dalam membayar PBB-P2 di UPPRD Johar Baru Jakarta periode tahun 2017-2019;

3. Untuk menganalisis upaya apa yang dilakukan dalam meningkatkan partisipasi masyarakat terhadap kepatuhan wajib pajak dalam membayar PBB-P2 di UPPRD Johar Baru Jakarta periode tahun 20172019.

\section{LANDASAN TEORI}

Mayangsari dalam jurnalnya dengan judul 'Analisis Kepatuhan Masyarakat dalam Membayar Pajak Bumi dan Bangunan Perdesaan dan Perkotaan di Kelurahan Kodamas Kabupaten Pandeglang (2017)", menjelaskan hasil penelitiannya dimana kepatuhan masyarakat Kelurahan Kodamas dalam membayar pajak bumi dan bangunan perdesaan dan perkantoran masih belum optimal, dimana masih kurangnya kesadaran masyarakat akan pentingnya membayar pajak bumi dan bangunan sektor perdesaan dan perkotaan sebagai kewajiban kepada Negara.

Prisma Anugrah dalam jurnalnya yang berjudul "Analisis Partisipasi Masyarakat dalam Pembayaran Pajak Bumi dan Bangunan Perdesaan dan Perkotaan di Kecamatan Palaran Kota Samarinda (2016)" Menjelaskan bahwa target dan realisasi dari pajak bumi dan bangunan untuk tahun 2013 mencapai target 90\% sementara untuk tahun 2014 dapat melebihi target sekitar 110\% tetapi untuk tahun 2015 mengalami banyak kendala sehingga sampai akhir tahun hanya bisa mencapai target sekitar 95\%.

Rahmawati, Dkk dalam jurnalnya dengan judul "Analisis Kepatuhan Masyarakat dalam Membayar Pajak Bumi dan Bangunan di Desa Ranjeng Kecamatah Ruas Kabupaten Serang (2014)', diketahui bahwa rata-rata kepatuhan masyarakat Desa Ranjeng dalam membayar pajak bumi dan bangunan masih belum optimal hal ini karena masih kurangnya pemahaman dan kesadaran masyarakat setempat akan pentingnnya membayar pajak bumi dan bangunan sebagai bentuk kewajiban kepada Negara.

Subhan Juniar Adithama, Dkk dalam jurnalnya yang berjudul 'Analisis Persepsi Masyarakat Terhadap Kewajiban membayar Pajak Bumi dan Bangunan di Kecamatan Slawi Kabupaten Tegal (2017)' hasil dari penelitian menjelaskan bahwa kesadaran masyarakat Kecamatan Slawi dalam membayar PBB sudah cukup tinggi, hal ini dikarenakan tingkat pendidikan yang mulai membaik di Kecamatan Slawi serta sosialisasi tentang PBB yang secara gencar oleh pemerintah belakangan ini. Namun, masih ada sebagian responden yang mengaku tidak ada waktu untuk membayar PBB sehingga mereka menunggu petugas pajak menagih ke rumah mereka.

Dari beberapa penelitian terdahulu diatas menunjukan bahwa masih terdapat masalah partisipasi masyarakat dalam pelaksanaan PBB P2, akan tetapi belum banyak penelitian yang memfokuskan penelitiannya pada analisis partisipasi masyarakat khususnya di wilayah UPPRD Provinsi DKI Jakarta dalam hal ini UPPRD Johar Baru.

Untuk menilai partisipasi masyarakat, penelitian ini menggunakan teori partisipasi masyarakat menurut Cohen dan Uphoff (Dwiningrum 2011:51). Teori tersebut berisi tentang partisipasi dalam pelaksanaan, dimana penulis ingin melihat pelaksanaan partisipasi masyarakat terhadap kepatuhan wajib pajak dalam membayar PBB-P2nya, indikator partisipasi antara lain 1) Keaktifan masyarakat dalam 
pelaksanaan partisipasi; 2) Kesedian memberikan sumbangan pikiran dan keahlian; 3) Kesedian memberikan sumbangan uang dan materi; 4) Tanggung jawab terhadap keberhasilan partisipasi.

Penelitian ini juga akan dikaji dari teori kepatuhan wajib pajak yang dapat dilihat dari indikator kepatuhan (OECD, 2004) yang dikutip Pohan (2017:160) adalah 1).Pendaftaran, 2).Penyampaian SPT, 3).Pelaporan, 4). Pembayaran.

Teori partisipasi masyarakat dan kepatuhan wajib pajak diatas dapat digunakan sebagai landasan teori untuk mengetahui bagaimana partisipasi masyarakat dalam melaksanakan kewajiban PBB P2, bagaimana masyarakat berperan aktif dalam membayar serta mendaftarkan tanah dan atau bangunan sebagai objek pajak, menyampaikan surat pemberitahuan pajak terhutang, serta melakukan pembayaran sesuai dengan jumlah yang tertera pada SPPT dengan tepat waktu.

\section{HASIL PENELITIAN DAN PEMBAHASAN}

1. Partisipasi masyarakat terhadap kepatuhan wajib pajak dalam membayar PBB-P2

Pajak Bumi dan Bangunan (PBB) merupakan pajak langsung yang dipungut oleh pemerintah di daerahnya masing masing, dimana hasil penerimaannya adalah untuk kepentingan masyarakat di daerah.

Masyarakat selaku wajib pajak harus memenuhi kewajiban mereka dengan cara membayar pajak sesuai dengan jumlah yang telah ditetapkan dengan tepat waktu, sehingga tidak terjadi penumpukan hutang pajaknya. Berdasarkan ketentuan dalam peraturan perpajakan serta dalam Sistem pemungutan pajak, fiscus berperan melaksanakan tugas seperti pembinaan, pelayanan, pengawasan, penerapan sanksi terhadap penundaan pemenuhan kewajiban perpajakan.

Fungsi pengawasan sangatlah penting dalam pemungutan pajak, untuk tercapainya penerimaan pajak itu sendiri. Maka dari itu tanpa adanya pengawasan dan kepatuhan masyarakat selaku wajib pajak maka akan mengakibatkan pemungutan tersebut tidak dapat berjalan dengan baik, yang berdampak penerimaan dari sektor pajak tidak tercapai, yang akan mengakibatkan terhambatnya pembangunan daerah sekitar. Dibawah ini disampaikan data wajib pajak yang melaksanakan pembayaran secara tepat waktu, terlambat, dan pembebasan pajak :

\begin{tabular}{|c|c|c|c|c|c|}
\hline Tahun & $\begin{array}{r}\text { SPPT } \\
\text { Terbit }\end{array}$ & $\begin{array}{r}\text { Tepat } \\
\text { Waktu }\end{array}$ & Terlambat & Pembebasan & $\%$ \\
\hline 2017 & 19.855 & 11.576 & 3242 & 5.020 & $89,76 \%$ \\
\hline 2018 & 19.926 & 11.690 & 2.312 & 5.845 & $87,62 \%$ \\
\hline 2019 & 19.988 & 11.097 & 4.786 & 3.837 & $84,63 \%$ \\
\hline
\end{tabular}

Berdasarkan tabel diatas dapat diketahui bahwa persentase pembayar PBB P2 belum mencapai target yang diharapkan, hal ini menunjukkan bahwa tingkat kepatuhan PBB P2 di wilayah UPPRD Johar Baru belum maksimal, akan tetapi wajib pajak sebagian besar telah berperan aktif dalam melaksanakan pembayaran PBB P2. Partisipasi masyarakat dalam memberikan ide atau gagasan belum optimal, akan tetapi sebagian wajib pajak turut serta mengajak masyarakat lainnya untuk membayar PBB secara tepat waktu.

Dalam melayani UPPRD Johar Baru telah memberikan pelayanan sebaik-baiknya kepada wajib pajak, hal ini terlihat dari hasil wawancara dengan beberapa wajib pajak bahwa pelayanan di UPPRD Johar Baru memuaskan, petugasnya ramah, sopan, tanggap cermat dan lugas dalam memberikan pelayanan, sehingga wajib pajak puas dengan kinerja petugas dalam melayani pembayaran PBB P2.

\section{Hambatan dalam Meningkatkan Partisipasi Masyarakat Terhadap Kepatuhan Wajib Pajak}

Ada berbagai hambatan yang dihadapi oleh UPPRD Johar Baru dalam melaksanakan pemungutan PBB P2, beberapa kendala yang ditemui petugas yaitu tingkat kesadaran masyarakat selaku wajib pajak yang masih kurang, hal ini karena kurangnya pengetahuan masyarakat selaku wajib pajak akan pentingnya membayar pajak, sebagian besar wajib pajak taat membayar pajaknya tetapi tidak memahami pendapatan 
yang diterima pemerintah daerah dari iuran PBB P2 akan digunakan untuk apa, sebagian besar wajib pajak belum mengetahui bagaimana proses pengembangan daerah out dibangun atau diperbaiki oleh pemerintah daerah dengan menggunakan pendapatan dari PBB P2.

Wajib Pajak tidak aktif dalam melaporkan perubahan alamat ataupun perubahan bangunan sehingga memperhambat kinerja petugas, contoh seperti objek pajak tanah kosong yang dimana pemilik selaku wajib pajak berpindah tempat sehingga objek pajak tersebut, dan petugas mengalami kesulitan atas kepemilikan objek pajak yang ada dilapangan. Masalah lain yaitu objek pajak yang bersumber dari warisan keluarga (tanah waris) masih belum diupdate perubahan kepemilikannya ke kantor UPPRD.

Ketidak beradaan wajib pajak di tempat tinggalnya merupakan salah satu hambatan yang didapat oleh petugas UPPRD Johar Baru pada saat melakukan survei lapangan, banyak bangunan / rumah kosong yang pemiliknya pindah ketempat lain sehingga tanah kosong dan juga adanya tanah sengketa yang tidak tahu kepemilikan atas hak tanah dan bangunan tersebut.

Meski demikian, Petugas UPPRD selalu menghimbau kepada masyarakat selaku wajib pajak untuk selalu melaporkan perubahan atas tanah dan bangunannya, mentaati kewajiban pajaknya secara tepat waktu, membayarkan hutang pajaknya, dan melakukan pemecahan atas akta kepemilikan tanah yang terkait dengan tanah waris atau hibah keluarga.

3. Upaya yang dilakukan dalam Meningkatkan Partisipasi Masyarakat terhadap Kepatuhan WP dalam membayar PBB-P2

Berbagai cara telah dilakukan petugas selaku pemerintah daerah agar tidak lagi menemukan masalah yang sama pada saat pendataan atau survei lapangan. Petugas UPPRD Johar Baru telah melakukan berbagai upaya agar wajib pajak memahami betapa pentingnya membayar PBB P2 salah satunya yaitu dengan sosialisasi dan memberi pengetahuan kepada warga tentang betapa pentingnya mambayar PBB P2 untuk pembanguanan serta kemajuan daerahnya, kegiatan ini dilakukan setiap tahun bekerjasama dengan kelurahan, kecamatan, hingga ke tingkat RT dan RW. Selain itu UPPRD Johar Baru menghimbau masyarakat melalui selembaran dan memasang spanduk/ baliho dibeberapa titik untuk mengingatkan kembali untuk embayar PBB-P2 secara tepat waktu. Petugas juga melakukan upaya pendataan ulang kepemilikan bangunan yang ditinggalkan oleh pemiliknya, seperti pemilik objek pajak atau bangunan tanah kosong serta bangunan yang merupakan warisan, dan senantiasa menghimbau warganya untuk selalu mengupdate kepemilikan atas tanah dan bangunan dan melaporkan perubahan atas objek pajak tersebut ke kantor UPPRD Johar Baru.

\section{KESIMPULAN}

Partisipasi masyarakat terhadap kepatuhan wajib pajak dalam membayar pajak bumi dan bangunan perkotaan dan perdesaan di unit pelayanan pajak dan retribusi daerah Johar Baru Jakarta periode tahun 20172019 dapat dibilang cukup efektif akan tetapi petugas masih menemukan beberapa kendala antara lain, masyarakat selaku wajib pajak kurang akan pengetahuan pentingnya membayar pajak, serta manfaat atas pembayaran pajak itu sendiri. Sebagian masyarakat belum membayar pajak tepat waktu, hal ini menyebabkan terjadinya penunggakan hutang PBB-P2. Sebagian besar wajib pajak kurang aktif dalam melaporkan perubahan objek maupun subjek pajaknya sehingga data kepemilikan tidak update. Upaya yang dilakukan dalam meningkatkan partisipasi masyarakat terhadap kepatuhan wajib pajak dalam membayar pajak bumi dan bangunan perdesaan dan perkotaan, petugas upprd setempat selaku pemerintah pemerintah daerah, telah melakukan berbagai upaya untuk masyarakat selaku wajib pajak memahami pentingnya membayar pajak terutama pajak bumi dan bangunan perdesaan dan perkotaan, melalui sosialisasi yang dilakukan beberapa kali dalam setahun melalui tingkat kelurahan atau kecamatan, serta menghimbau masyarakat melalui selembaran serta memasang spanduk dan baliho di beberapa titik ruas jalan agar masyarakat dapat mengingat kewajiban membayar pajak dan pentingnya membayar pajak serta petugas juga telah melakukan tinjau lapangan untuk memastikan objek maupun subjek pajak sesuai.

\section{SARAN}

1. Wajib Pajak atau Masyarakat diharapkan secara aktif dan tepat waktu dalam melakukan pembayaran pajak bumi dan bangunan sektor perdesaan, serta masyarakat selaku wajib pajak diharapkan melaporkan perubahan alamat serta bangunannya kepada petugas agar petugas tidak mendapatkan kendala yang sama dan agar petugas saat melakukan pekerjaannya tidak terhambat dengan data yang tidak valid/ tidak sesuai dengan yang ada dilapangan. Zaman telah berubah berbagai cara dapat dilakukan oleh masyarakat 
selaku wajib pajak untuk secara aktif melaporkan perubahan atas objek pajaknya, antara lain masyarakat bisa melakukan pemotretan pada objek yang memiliki perubahan sebagai lampiran perubahan atas tanah dan bangunan melalui portal online UPRD yang dimana data yang diupload atau data yang bersifat rahasia hanya bisa diakses oleh petugas untuk mengupdate data. Masyarakat selaku wajib pajak yang mempunyai akun portal online tersebut mengupdate perubahan atas tanah dan bangunannya; Petugas juga dapat berkerjasama dengan PPSU (pekerja penanganan sarana dan prasarana) atau yang hangat disebut dengan tim orange untuk membantu melakukan pengambilan gambar objek pajak yang merupakan bangunan yang terdaftar sebagai wajib pajak agar mempermudah petugas untuk mengetahui apakah objek pajak tersebut terdapat perubahan.

2. Petugas atau Pemerintah Daerah agar mengoptimalkan kegiatan sosialisasi sesering mungkin untuk memberitahukan pentingnya membayar PBB P2 untuk pembangunan Daerah setempat, dengan cara mendatangi langsung rumah Wajib Pajak (penyuluhan door to door terjadwal) agar masyarakat selaku wajib pajak mengetahui pentingnya membayar pajak, selaku masyarakat selaku wajib pajak yang menerima warisan dihapkan pula untuk melaporkan atas kepemilikan tanah serta penggantian nama kepemilikan tanah serta pemisahan akta kepemilikan.

3. Pemerintah Daerah diharapkan dapat membantu masyarakat sekitar selaku wajib pajak untuk mengadakan pemutihan untuk akta kepemilikan, misal pemerintah daerah mengadakan pembuatan atau pemisahan akta kepemilikan secara gratis dengan syarat pembuatan atau pemisahan akta kepemilikan yang biasanya hal ini diperlukan oleh wajib pajak yang menerima warisan, serta memberikan keringanan pajak terhutang.

4. Petugas dapat bergerak aktif mencaritahu kepemilikan objek pajak yang dikosongkan oleh pemiliknya, dengan cara memberikan pemberitahuan atau peringatan untuk segera melaporkan objek pajaknya sesuai dengan kondisi real, misalnya dengan cara menempelkan stiker pada bangunan tersebut agar pada saat pemilik bangunan atau wajib pajak datang untuk melihat bangunannya mereka mengetahui dan diharapkan segera datang dan melaporkan kepada petugas UPPRD.

5. Pemerintah Daerah atau Petugas UPPRD memberikan apresiasi bagi wajib pajak yang taat dalam membayar PBB-P2 seperti hadiah dan dilakukan secara terbuka atau dilakukan pada saat melakukan sosialisasi terkait pentingnya membayar pajak. Agar Masyarakat selaku wajib pajak lainnya terdorong untuk taat dalam membayar pajaknya.

\section{REFERENSI}

\section{Dokumen :}

Undang-Undang Nomor 12 Tahun 1985 Tentang Pajak Bumi dan Bangunan.

Undang-Undang Nomor 12 Tahun 1994 Tentang Pajak Bumi dan Bangunan.

Undang-Undang Nomor 28 Tahun 2009 Tentang Pajak dan Retribusi Daerah.

Peraturan Daerah Nomor 6 Tahun 2010 Tentang Ketentuan Umum Pajak Daerah.

Peraturan Daerah Provinsi DKI Jakarta Nomor 16 Tahun 2011 Tentang Pajak Bumi dan Bangunan Perdesaan dan Perkotaan.

Peraturan Gubernur Provinsi DKI Jakarta Nomor 24 Tahun 2018 Tentang Nilai Jual Objek Pajak Bumi dan Bangunan Perdesaan dan Perkotaan.

\section{Buku :}

Achmad Tjahjono; Muh. Fakhri Husein. 2009. Perpajakan. Yogyakarta: STIM YPKN

Anggara, Sahaya. 2012. Ilmu Administrasi Negara. Bandung: Pustaka Setia

Azis Samudra, Azhari. 2015. Perpajakan di Indonesia. Jakarta : PT Raja Grafisindo Persada

H.A.R. Tilaar. 2009. Kekuasaan dan Pendidikan:Kajian Manajemen Pendidikan Nasional dalam Pusaran Kekuasaan. Jakarta: Rinika Cipta

Ibrahim, Amir. 2007. Teori dan Konsep Pelayanan Publik serta Implementasinya. Bandung: CV Mandar Maju

Irra, Chisyanti Dewi. 2011. Pengantar Ilmu Administrasi. Jakarta: PT Prestasi Pustakaraya

Mardiasmo. 2011. Perpajakan Edisi Revisi 2011. Yogyakarta : CV. Andi Offset

Mardiasmo. 2016. Perpajakan. Jakarta: Salemba Empat.

Pohan, Chairil Anwar. 2017. Pembahasan Komprehensif Pengantar Perpajakan Teori dan Konsep Hukum Pajak Edisi 2. Jakarta: Mitra Wancana Media 
Rahmat, Abdul. 2010. Panduan Pelaksanaan Administrasi Pajak untuk Karyawan, Pelaku Bisnis dan Perusahaan. Bandung: Nusantara

Rahmat. 2013. Filsafat Administrasi. Bandung: Pustaka Setia

Resmi Siti. 2017. Perpajakan Teori dan Kasus. Yogyakarta: Salemba Empat

Samudra, Azhari Azis. 2015. Perpajakan di Indonesia. Jakarta: Raja Grafindo Persada.

Soemitro, Rochmat. 2013. Perpajakan Edisi Revisi 2011. Bandung: Eresco

Waluyo. 2013. Perpajakan Indonesia. Jakarta: Salemba Empat.

\section{Jurnal :}

Mayangsari. 2017. Analisis Kepatuhan Masyarakat dalam Membayar Pajak Bumi dan Bangunan Perdesaan dan Perkotaan di Kelurahan Kodamas Kabupaten Pandeglang http://repository.fisip-untirta.ac.id/870/

Prisma Anugrah. 2016. Analisis Partisipasi Masyarakat dalam Pembayarana Pajak Bumi dan Bangunan Perdesaan dan Perkotaan di Kecamatan Palaran Kota Samarinda. https://ejournal.an.fisip-unmul.ac.id/

Rahmawati. 2014. Analisis Kepatuhan Masyarakat dalam Membayar Pajak Bumi dan Bangunan di Desa Ranjeng Kecamatan Ciruas Kabupaten Serang https://stiami.ac.id/index.php/jurnal/

Subhan Juniar Adithama. 2015. Analisis Persepsi Masyarakat Terhadap Kewajiban membayar Pajak Bumi dan Bangunan di Kecamatan Slawi Kabupaten Tegal https://ejournal3.undip.ac.id/index.php/jpgs/article/view/10894/10570

May Yohana Istiana. 2009. Analisis Kepatuhan Wajib Pajak dalam membayar Pajak Bumi dan Bangunan (Studi pada Kantor Pelayanan Pajak Pratama Kapenjen) http://eprints.umm.ac.id/ Jonathan Di Jhon. Texation, Development State Capacity and Proverty Reduction. https://onlinelibrary.wiley.com/ 